DOI: https://doi.org/10.24144/2409-6857.2020.2(56).35-39

УДК 338.1

Готра В.В., Ігнатко М.I.

\title{
ОСОБЛИВОСТІ ІННОВАЦІЙНОЇ ДІЯЛЬНОСТІ АГРОПРОМИСЛОВИХ ПІДПРИЕМСТВ УКРАЇНИ
}

\begin{abstract}
Стаття присвячена дослідженню особливостей інновачійної діяльності на прикладі компанії «НІБУЛОН». Розкрито специфіку впровадження інновацій підприсмством. Проведено моніторинг зовнішньоекономічної, кадрової, екологічної політики компанії «НІБУЛОН». Графічно зображено динаміку експорту групи компаній «НІБУЛОН» у розрізі загального експорту Украӥни. Наведено напрямки заохочення підприємством молодих спечіалістів. Проаналізовано використання інформачійних технологій провідним аграрним підприємством. Створено матрищю БКГ за видами діяльності компанії «НІБУЛОН».
\end{abstract}

Ключові слова: інноваџуійний процес, інноваџійна діяльність, інноваџійний розвиток, кадрове забезпечення, експортний потенціал, імідж компанії.

Постановка проблеми. Інноваційна діяльність $\epsilon$ рушійною силою розвитку національної економіки, запорукою економічного зростання. Сучасні можливості участі суб'єктів господарювання у зовнішньоекономічній діяльності відкривають перед ними нові горизонти. Особливо це стосується агропромислових підприємств, які мають значні природно-кліматичні переваги над іноземними виробниками продукції АПК.

Аналіз останніх досліджень і публікацій. Проблемам забезпечення інноваційного розвитку агропромислового виробництва присвячені праці багатьох науковців. Дану тематику досліджували іноземні та українські вчені: Шумпетер I., Длугопольський О., Кизим М., Черваньов Д., Левченко Н., Павлова Г., Зубець М., Дацій О., Гончаренко О. Хоч наукових напрацювань на дану тематику i $€$ багато, але чимало питань залишаються відкритими та вимагають подальшого дослідження.

Формулювання цілей статті. Метою цієї статті $\epsilon$ аналіз особливостей інноваційної діяльності агропромислових підприємств України на прикладі ТОВ СП «НІБУЛОН».

Опис основного матеріалу дослідження. Од-

(C) Готра В.В., д.е.н., доцент, професор кафедри економіки та підприємництва ДВНЗ «Ужгородський національний університет», м. Ужгород, email: viktoriya.hotra@uzhnu.edu.ua Ігнатко М.I., аспірант кафедри економіки i підприємництва, ДВНЗ « Ужгородський національний університет», м. Ужгород, email: mariia.ignatko@uzhnu.edu.ua ним із найбільших виробників агропромислової продукції в Україні є компанія «НІБУЛОН», яка уже багато років поспіль посідає перше місце у рейтингу фірм-експортерів. У 2019 році ії частка ринку складала 9\% [4]. Динаміку експорту групи компаній «НІБУЛОН» у розрізі загального експорту України наведено на рис. 1.

Спостерігаємо тенденцію нарощування експорту продукції АПК, починаючи із 2017-2018 маркетингового року. У 2019-2020 маркетинговому році цей показник зріс майже у півтора рази у порівнянні із 2017-2018 роком.

Завдяки даному підприємству та його унікальній логістичній системі наша держава позиціонується на міжнародній арені як постачальник високоякісного зерна. Агропромислова продукція компанії «НІБУЛОН» експортується у 70 країн світу, станом на 2019 рік найбільше української сільськогосподарської продукції імпортував Китай (19\%). За останній маркетинговий рік на $12,8 \%$ зріс експорт продукції сільського господарства до країн Європейського Союзу: Нідерландів, Бельгії, Данії, Фінляндії, Франції, Німеччини, Італії, Португалії, Іспанії. На думку заступник генерального директора 3 торгівлі Володимира Славінського, це відбулося завдяки високій якості продукції, що постачає «НІБУЛОН», та дотриманню всіх необхідних норм харчової безпеки. Однією із найважливіших переваг цього підприємства $€$ наявність розвиненої інфраструктури, що дає можливість безперешкодно приймати, зберігати, відвантажувати продукцію АПК, контролювати іiі якість [4]. 


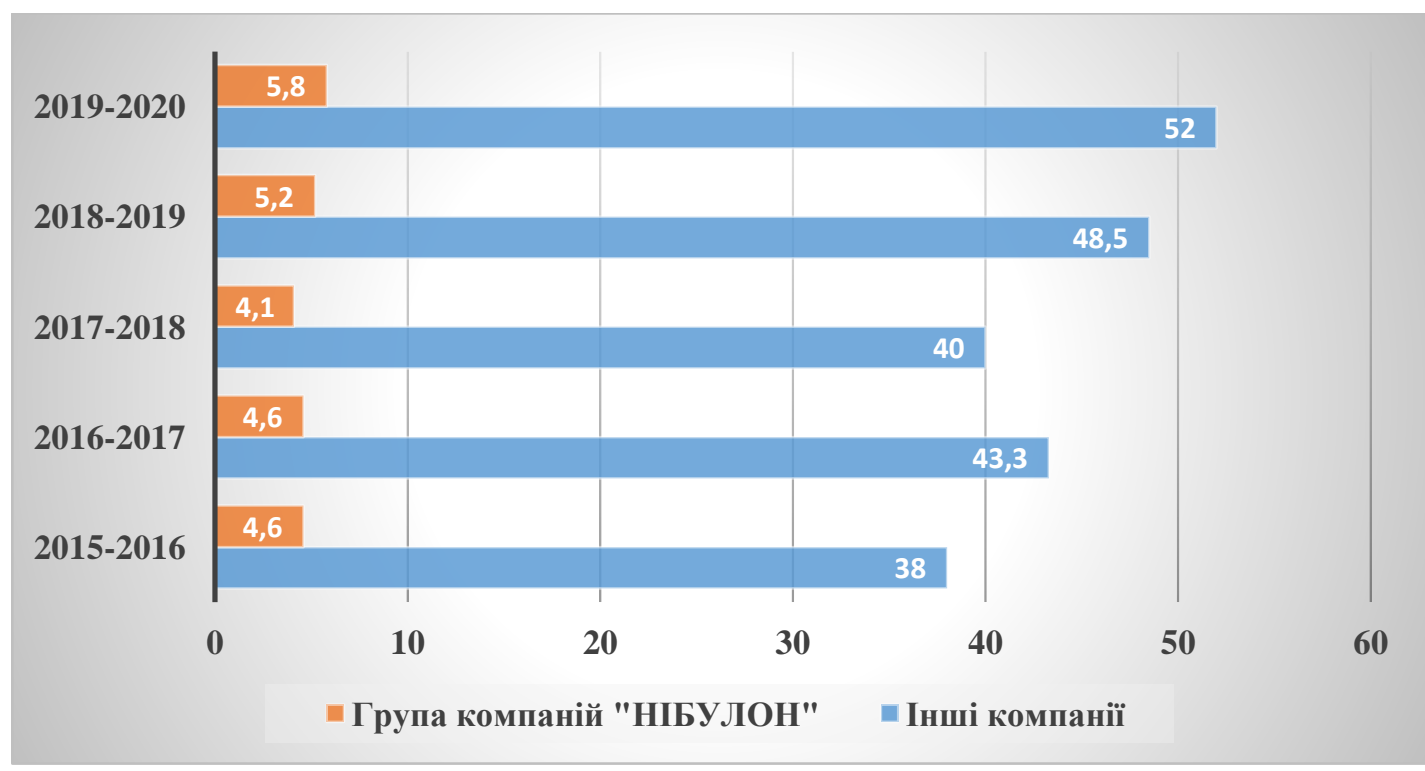

Рис. 1 Динаміка експорту групи компаній «НІБУЛОН» у розрізі загального експорту України за маркетинговими роками (млн тонн)

У 2019 році рекордно зросли обсяги виробництва агропромислової продукції та складали 370 тис. тонн.

Частка компанії в загальному експорті зернової групи (пшениця, ячмінь, кукурудза, сорго, жито) становила 9,3 \%, олійної групи (соя, ріпак, насіння соняшнику) - 6,1 \% [4]. Структура експорту сільськогосподарських культур компанії «НІБУЛОН» станом на 2019 рік наведена на рис. 2.

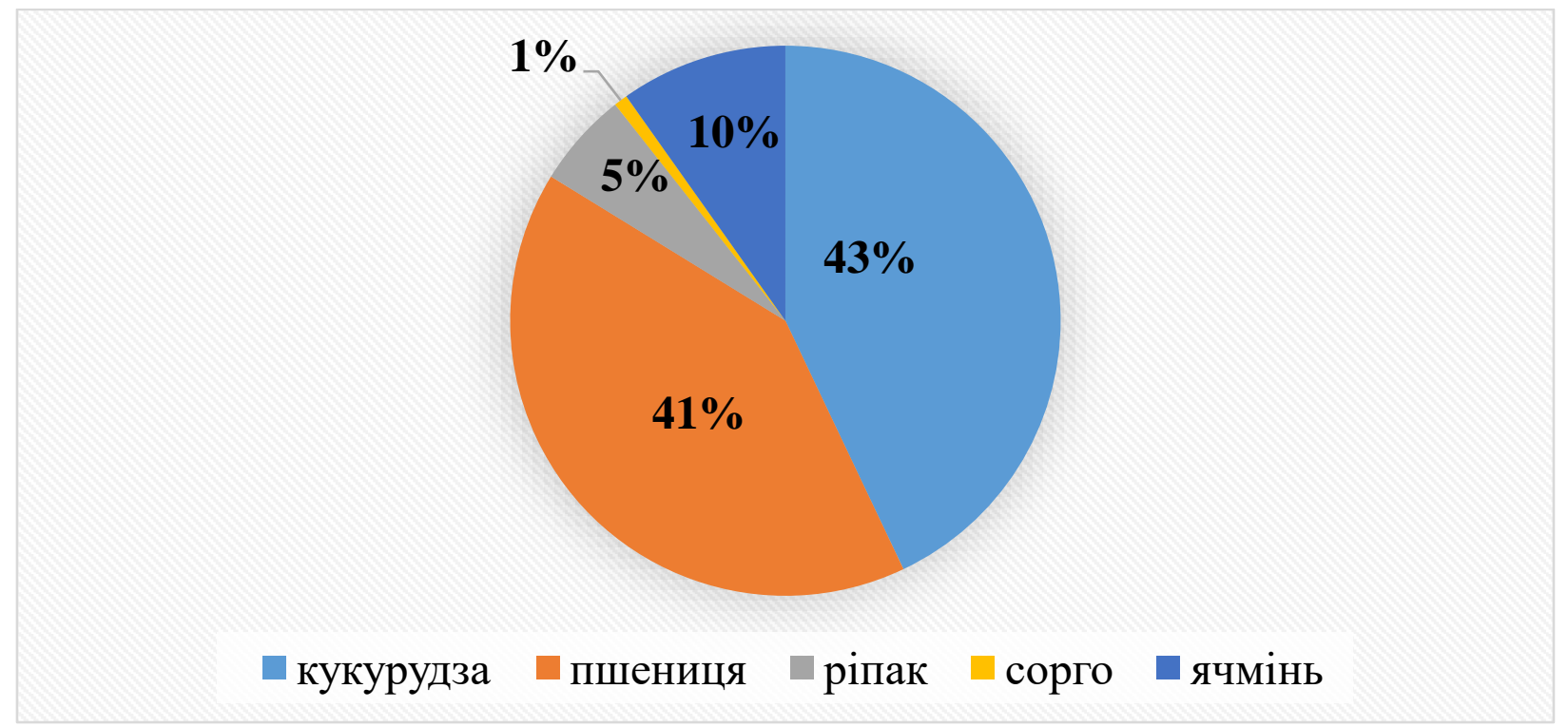

Рис. 2 Структура експорту сільськогосподарських культур компанії «НІБУЛОН»

Як видно із рис.2, основними експортними культурами є кукурудза, пшениця та ячмінь.

Основними чинниками, які впливають на забезпечення конкурентоспроможності експортної продукції компанії «НІБУЛОН», $є$ не лише висока якість та економічні умови продажу, а й ряд нецінових факторів: унікальність, ефективність бази для поширення інформації про продукцію, динамізм збуту i можливість 36 швидкого реагування на ринкові досягнення [3, c.3].

На прикладі ТОВ СП «НІБУЛОН» можна виділити кілька груп чинників, що впливають на ефективність виробництва та діяльності трейдера на ринку сільськогосподарської продукції: техніко-технологічні, організаційногосподарські, загальноекономічні, природні [6].

У рейтингу найбільш інноваційних компаній 
України за версією журналу «Forbes» станом на 2016 рік «НІБУЛОН» посів 15 місце, поступившись аграрній компанії МХП, яка у загальному рейтингу зайняла 8 місце $[1 ; 2]$.

Головною метою діяльності «НІБУЛОН» $є$ випуск екологічно чистої та безпечної для вживання конкурентоспроможної продукції. Екологічна політика компанії покликана забезпечувати ефективне використання природних ресурсів, зберігати навколишне середовище та забезпечувати екологічну безпеку виробничих процесів.

Запорукою збереження підприємством лідерських позицій на ринку $є$ також належне кадрове забезпечення. У 2020 році за результатами міжнародного дослідження Randstad Employer Brand Research «НІБУЛОН» отримав відзнаку «Найпривабливіший роботодавець України в галузі сільського господарства 2020 року». Головними принципами кадрової політики «НІБУЛОНа» - «залучення до роботи талановитої молоді - випускників вузів, 3 яких виховуються майбутні лідери - менеджери середньої та вищої ланки управління» [4]. Досягається це за рахунок тісної співпраці із закладами освіти, зокрема, студенти можуть проходити практики на підприємстві та ознайомлюватися із специфікою його діяльності.

Молодих спеціалістів «НІБУЛОН» заохочує за рахунок:

• разової допомоги при зміні місця
проживання;
• оплати оренди житла;
• часткового відшкодування вартості
харчування;
• можливості стрімкого кар'єрного росту;
• стабільної заробітної плати;
• соціальних виплат;
• придбання житла компанією молодому

спеціалісту, який більше $3-x$ років пропрацював на керівній посаді [4].

На території СС3 «НІБУЛОН» діє ліцензований навчальний центр, який займається професійно-технічним навчанням, перепідготовкою, підвищенням кваліфікації 3 видачею документів державного зразка за такими основними суднобудівними спеціальностями: складальник-добудовник судновий; складальник корпусів металевих суден; фрезерувальник; токар; слюсар-монтажник судновий; слюсарремонтник судновий; слюсар 3 експлуатації та ремонту газового устаткування; електрозварник на автоматичних та напівавтоматичних машинах; електрогазозварник; трубопровідник судновий; трубозгинальник судновий; стропальник. У навчальному центрі робітники безкоштовно та без відриву від виробництва за індивідуальною та груповою формами навчання підвищують свій кваліфікаційний рівень, при цьому обов'язково проходять навчання 3 питань охорони праці. Працівники згідно 3 індивідуальним планом проходять спочатку теоретичне, а потім професійно-практичне навчання із закріпленими за ними висококваліфікованими інструкторами фахівцями компанії «НІБУЛОН». У 2019 році навчальний центр успішно пройшов державну атестацію навчальних закладів різних типів i форм власності, чим підтвердив високий рівень кваліфікації [5].

Компанією постійно оновлюється матеріально-технічне забезпечення. «НІБУЛОН» володіє найсучаснішим у нашій державі автопарком вантажного транспорту. Активно розвивається автомобільна та річкова логістика. До прикладу, у 2017 році «НІБУЛОН» наростив автопарк, закупивши 60 нових тягачів, які з'єднують річкові термінали підприємства із виробниками агропромислової продукції у радіусі 80-100 кілометрів. Компанія щотижня імпортує сучасне обладнання від передових виробників агропромислового устаткування у світі.

ТОВ СП «НІБУЛОН» активно використовує сучасні інформаційні технології. Ще у 2015 році було запроваджено корпоративну систему управління IT-Enterprise, за допомогою якої вдалося підвищити ефективність виробництва, мінімізувати витрати, модернізувати управлінські процеси [4].

Важливим елементом позиціювання підприємства на міжнародній арені є створення позитивного іміджу компанії. Об'єктами формування іміджу ТОВ СП «НІБУЛОН» виступають наступні.

1. Рейтинги. Компанія постійно бере участь у певних змаганнях зі своїми конкурентами, рейтинг яких постійно друкується у 3МI, а також висвітлює власні результати у радіо- та телепередачах, інтернеті.

2. Благодійні акції. ТОВ СП «НІБУЛОН» регулярно допомагає дитячим будинкам та установам, а також медичним закладам у регіонах існування власних підрозділів.

3. Участь у виставках та презентаціях у країні та закордоном. Компанія відвідує світові виставки та створює презентації результатів діяльності підрозділів на спеціальних заходах «Днях поля» тощо.

Сильний імідж може дати суттєву перевагу, особливо в тому випадку, коли підприємство не відрізняється або незначно відрізняється на ринку від конкурентів. Таким чином, формуючи напрями підвищення конкурентоспроможності 
ТОВ СП «НІБУЛОН», що займається зовнішньоекономічною діяльністю, потрібно розробити конкурентну стратегію збільшення частки світового ринку зернотрейдерів, а також звернути увагу на підтримку заходів щодо формування позитивного іміджу [3, с.4].

Проаналізувавши усі напрямки діяльності компанії «НІБУЛОН» можна побудувати матрицю БКГ (таблиця 1).

Таблиця 1

\section{Матриця БКГ за видами діяльності компанії «НІБУЛОН» [6]}

\begin{tabular}{|c|c|c|c|}
\hline \multirow{3}{*}{ 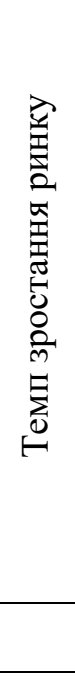 } & Високий & $\begin{array}{c}\text { 1. Вантажне та пасажирське } \\
\text { суднобудівництво } \\
\text { 2. Річкове судноплавство } \\
\text { 3. Будівництво нових елеваторів } \\
\text { та перевантажувальних } \\
\text { терміналів }\end{array}$ & $\begin{array}{l}\text { 1. Експорт зернових культур } \\
\text { 2. Вирощування та продаж на } \\
\text { експорт власних зернових. }\end{array}$ \\
\hline & Низький & $\begin{array}{l}\text { 1. Виробництво власних } \\
\text { ковбасних виробів } \\
\text { 2. Тваринництво }\end{array}$ & $\begin{array}{c}\text { 1. Використання } \\
\text { автомобільної та логістичної } \\
\text { інфраструктури у доставці } \\
\text { зернових. }\end{array}$ \\
\hline & & Низька & Висока \\
\hline & & Відносне & я ринку \\
\hline
\end{tabular}

ТОВ СП «НІБУЛОН» високими темпами нарощує експорт зернових культур та розвиває інфраструктурне забезпечення (вантажне, пасажирське судноплавство тощо).

Висновки i перспективи подальших досліджень. Провідна українська аграрна компанія «НІБУЛОН» досягає лідируючих позицій за рахунок зваженої зовнішньоекономічної, кадровою, фінансової, екологічної політики. Інноваційний розвиток підприємства забезпечується активним впровадженням інформаційних технологій, безупинним оновленням матеріально-технічного забезпечення, тісною міжнародною співпрацею, контролем за якістю сільськогосподарської продукції.

\section{ПЕРЕЛІК ВИКОРИСТАНИХ ДЖЕРЕЛ}

1. Forbes: Врятувати майбутне (перший рейтинг найінноваційніших компаній України). URL: https://www.agrilab.ua/forbes-vryatuvaty-majbutnye-pershyj-rejtyng-najinnovatsijnishyh-kompanijukrayiny/

2. Ігнатко М.I. IT-інновації в управлінні розвитком агропромислового виробництва. Інформаційні технології у житті студентів та молодих науковців Закарпаття: матеріали V регіональної науковопрактичної конференції, м.Ужгород, 07 листопада 2019p. Ужгород, 2019.

3. Новак I.М. Напрями підвищення конкурентоспроможності продукції українських виробників на зовнішньому ринку. Економіка АПК. 2011. №3. С. 2-5.

4. Офіційний сайт ТОВ СП «НІБУЛОН». URL: https://nibulon.com/

5. Сталий розвиток. URL: https://www.nibulon.com/uploads/files/Inform\%202018-2019\%20mr.pdf

6. Уханова I.О., Дмитрієв П.Д. Особливості зовнішньоекономічної діяльності трейдера на світовому ринку зерна (на прикладі ТОВ СП «НІБУЛОН»). URL: https://conf.ztu.edu.ua/wpcontent/uploads/2018/09/334.pdf

\section{REFERENCES}

1. Forbes: Vriatuvaty maibutnie (pershyi reitynh naiinnovatsiinishykh kompanii Ukrainy) [Forbes: Save the future (the first rating of the most innovative companies in Ukraine)]. (n.d.). Retrieved from: 
https://www.agrilab.ua/forbes-vryatuvaty-majbutnye-pershyj-rejtyng-najinnovatsijnishyh-kompanij-ukrayiny [in Ukrainian].

2. Ihnatko, M. I. (2019). IT-innovatsii v upravlinni rozvytkom ahropromyslovoho vyrobnytstva [ITinnovations in the management of agro-industrial production]. Proceedings from: $\mathrm{V}$ rehionalna naukovopraktychna konferentsiia «Informatsiini tekhnolohii u zhytti studentiv ta molodykh naukovtsiv Zakarpattia»The V regional scientific-practical conference «Information technologies in the life of students and young scientists of Transcarpathia». Uzhhorod [in Ukrainian].

3. Novak, I. M. (2011). Napriamy pidvyshchennia konkurentospromozhnosti produktsii ukrainskykh vyrobnykiv na zovnishnomu rynku [Directions for increasing the competitiveness of Ukrainian producers' products on the foreign market]. Ekonomika APK - Economics of AIC, 3, 2-5 [in Ukrainian].

4. Ofitsinyi sait TOV SP «NIBULON» [Official site of JV NIBULON LLC] (n.d.). Retrieved from: https://nibulon.com/ [in Ukrainian].

5. Stalyi rozvytok [Sustainable development] (n.d.). Retrieved from: https://www.nibulon.com/uploads/files/Inform\%202018-2019\%20mr.pdf [in Ukrainian].

6. Ukhanova, I. O., \& Dmytriev, P. D. (n.d.). Osoblyvosti zovnishnoekonomichnoi diialnosti treidera na svitovomu rynku zerna (na prykladi TOV SP «NIBULON») [Peculiarities of a trader's foreign economic activity on the world grain market (on the example of JV NIBULON LLC)]. (n.d.). Retrieved from: https://conf.ztu.edu.ua/wp-content/uploads/2018/09/334.pdf [in Ukrainian]. 